\title{
Soil Development from Volcanic Ash Based on Different Pyroclastic Composition
}

\author{
Asmita Ahmad*, Muchtar Salam Solle and Christianto Lopulisa \\ Department of Soil Science, Faculty of Agriculture, Hasanuddin University. Kampus Unhas, Jl. Perintis \\ Kemerdekaan Km.10, Postal Code: 90245, Makassar, South Sulawesi Province, Indonesia \\ *email: asmita.ahmad@agri.unhas.ac.id; asmitaahmad@yahoo.com
}

Received May 27, 2019; Revised July 17, 2019; Accepted 5 September 2019

\begin{abstract}
Potential volcano in several provinces in Indonesia played a significant role in the formation and quality of soil development. Soils that developed from the volcanic ashes are often thought to contribute greatly to improve soil fertility, without regard to the nature and composition of the volcanic ash produced. Volcanic ash generated from the results of volcanic activity has a different composition, there are basaltic, andesitic and granitic, thereby affecting the formation and characteristics of the soil. The objective of this study was to determine the soil development from different types of pyroclastic materials generated from the Lokon volcano in North Sulawesi. The study was carried out at the foot of Mount Lokon with three-point of coordinates, namely (1) $1^{\circ} 21^{\prime} 18.0^{\prime \prime} \mathrm{N}$ and $124^{\circ} 49^{\prime} 20.2^{\prime \prime} \mathrm{E}$, (2) $1^{\circ} 21^{\prime} 30.2^{\prime \prime} \mathrm{N}$ and $124^{\circ} 49^{\prime} 2.8^{\prime \prime} \mathrm{E}$, (3) $1^{\circ} 24^{\prime} 23.70^{\prime \prime} \mathrm{N}$ and $124^{\circ} 52^{\prime} 17.30^{\prime \prime} \mathrm{E}$. Arc-GIS 10.3 software was used for mapping the location of the study with the base maps of a regional geological map and the topography map. Soil characteristics including texture, $\mathrm{pH}$, organic-C, Cation Exchange Capacity (CEC), and mineral contents were determined. The results show that there are two types of pyroclastic as the source of soil development from volcanic ash, namely; 1) basaltic pyroclastic with $43.26 \% \mathrm{SiO}_{2}$ that is resulted from the first magmatic eruption and 2) andesitic pyroclastic with $5.09 \% \mathrm{SiO}_{2}$ that is resulted from the late magmatic eruption. Basaltic pyroclastic contains $\mathrm{Fe} 37.63 \%, \mathrm{Al} 11.35 \%, \mathrm{Ca} 13.17 \%$ and $\mathrm{Mg} 5.69 \%$, while andesitic pyroclastic contains $\mathrm{Fe} 38.35 \%, \mathrm{Al} 6.87 \%$, and $\mathrm{Ca} 8.61 \%$. Rainfall ranges from 2000 to $3500 \mathrm{~mm} \mathrm{yr}^{-1}$, which helped the soil formation and influenced the characteristics of the soil, such as sandy loam texture, soil organic-C content $3.08 \%, \mathrm{CEC} 23.24 \mathrm{cmol}(+) \mathrm{kg}^{-1}$ and clay CEC $148.93 \mathrm{cmol}(+) \mathrm{kg}^{-1}$. The clay minerals in the soil consist of vermiculite, kaolinite and, halloysite. Cation supply from basaltic pyroclastic influences the formation of vermiculite mineral, whereas andesitic pyroclastic largely influences the formation of the kaolinite mineral. The formation of soil texture with a predominance of the sand fraction is more influenced by the type of andesitic pyroclastic that is more resistant to weathering processes.
\end{abstract}

Keywords: Andesitic, kaolinite, pyroclastic, soil, volcanic ash

\begin{abstract}
ABSTRAK
Potensi gunung api di beberapa provinsi di Indonesia memberikan peran yang besar dalam proses pembentukan dan kualitas tanah yang dihasilkan. Tanah-tanah yang berkembang dari abu vulkan sering diduga memberikan kontribusi besar terhadap peningkatan kesuburan tanah, tanpa memperhatikan sifat dan komposisi dari abu vulkan yang dihasilkan. Abu vulkan yang dihasilkan dari hasil aktivitas vulkanisme memiliki komposisi yang berbedabeda, ada yang bersifat basaltik, andesitik dan granitik, sehingga mempengaruhi proses pembentukan dan karakteristik tanah yang dihasilkan. Penelitian ini bertujuan untuk mengetahui perkembangan tanah dari abu vulkan yang berasal dari tipe piroklastik berbeda yang dihasilkan dari aktivitas Gunung api Lokon di Sulawesi Utara. Penelitian dilakukan di kaki Gunung Lokon, dengan koordinat lokasi pengamatan, yaitu; (1) $1^{\circ} 21^{\prime}$ ' $18.0^{\prime \prime} \mathrm{LU}$ and $124^{\circ}$ 49' 20.2” BT, (2) $1^{\circ} 21^{\prime} 30.2^{\prime \prime} \mathrm{LU}$ and $124^{\circ} 49^{\prime} 2.8^{\prime \prime}$ BT, (3) $1^{\circ} 24^{\prime} 23.70^{\prime \prime} \mathrm{LU}$ and $124^{\circ} 52^{\prime} 17.30$ “BT. Sofware Arc-Gis 10.3 digunakan dalam memetakan lokasi penelitian dengan peta dasar berupa peta geologi dan peta topografi. Analisis tanah meliputi tekstur, pH, C-Organik, kapasitas tukar kation (KTK), dan persentase mineral. Terdapat dua tipe piroklastik sebagai sumber pembentukan tanah abu vulkan, yaitu 1) piroklastik basaltik dengan kadar $\mathrm{SiO}_{2}$ sebesar $43,26 \%$ yang dihasilkan dari first magmatic eruption dan 2) piroklastik andesitik dengan kadar $\mathrm{SiO}_{2}$ sebesar 51,09\%
\end{abstract}

J Trop Soils, Vol. 24, No. 3, 2019: 135-140

ISSN 0852-257X; E-ISSN 2086-6682 
yang dihasilkan dari late magmatic eruption. Piroklastik basaltik mengandung Fe 37,63\%, Al 11,35\%, Ca 13,17\% dan dan Mg 5,69\%, sedangkan yang bersifat andesitik mengandung Fe 38,35\%, Al 6,87\%, dan Ca 8,61\%. Curah hujan berkisar 2000-3500 $\mathrm{mm} \mathrm{th}^{-1}$ membantu pembentukan tanah dan mempengaruhi karakter tanah yang terbentuk, seperti membentuk tanah dengan tekstur lempung berpasir, kandungan C-organik tanah 3,08\%, KTK 23,24 cmol(+) $\mathrm{kg}^{-1}$ dan KTK liat 148,93 cmol(+) $\mathrm{kg}^{-1}$. Kandungan mineral liat tanah yang terbentuk adalah vermikulit, kaolinit dan haloisit. Suplai kation dari piroklastik basaltik mempengaruhi pembentukan mineral vermikulit, sedangkan piroklastik andesitik lebih banyak mempengaruhi pembentukan mineral kaolinit. Pembentukan tekstur tanah dengan didominasi fraksi pasir lebih banyak dipengaruhi oleh tipe piroklastik andesitik yang lebih resisten terhadap proses pelapukan.

Kata kunci: Tanah; abu volkan; piroklastik; andesitik; kaolinit

\section{INTRODUCTION}

Volcanoes in Indonesia are affected by the activity of the Indo-Australian tectonic plate in the western Pacific and Australian plates in the eastern part (Katili 1975; Hall 2012). This led to intensive volcanic activities in some provinces, by producing magma and lava as effusive activity and ash bursts as explosive activity. The effusive activity of volcanoes will produce massive parent materials with stabile mineral components, and has a low impact on weathering process, while the explosive activity produces porous parent materials with broken mineral components, and has a high impact on weathering process. So both of these activities have significant influences on soil parent material resources that will be formed and soil quality that will be produced (Ugolini and Zasoski 1979; Babiera and Takahashi 1997; Siebert et al. 2015).

Mount Lokon is located in the city of Tomohon, North Sulawesi province. The activity of Mount Lokon has been started since 1829 with explosive eruption activities by removing ash/dust, rocks fragments, and bombs. The most intensive explosive eruption period occurred almost every year from 2000-2003, then continued in 2007-2015, and 20172018. A high level of intensity of Mount Lokon eruption has resulted in many materials for soil development in the area. Mount Lokon is classified as a stratovolcano that produces more volcanic ash than lava.

Soils that developed from volcanic ash are often thought to contribute greatly to improve soil fertility (Dahlgren et al. 2004; Torrence 2012), without regard to the nature and composition of the volcanic ash-producing (Cronin et al. 2014), so that the soil management often requires a lot of additional organic matter to improve plant nutrient uptake (Rahayu et al. 2014; Dariah et al. 2015). Volcanic ash generated from volcanic activity has different composition including basaltic, andesitic, trachytic, rhyolitic and granitic, thereby affecting the formation and characteristics of the soil (Gourgaud et al. 2000; Prévosto et al. 2004; Arnalds 2013). Therefore, the objective of this study was to determine the development of soil from volcanic ash originating from different types of pyroclastic materials of Lokon volcano in North Sulawesi.

\section{MATERIALS AND METHODS}

\section{Soil Sampling}

The study was carried out at the foot of Mt. Lokon, which is part of the Tondano watershed located at a three-point location, namely (1) $1^{\circ} 21^{\text {, }}$ $18.0^{\prime \prime} \mathrm{N}$ and $124^{\circ} 49^{\prime} 20.2^{\prime \prime} \mathrm{E},(2) 1^{\circ} 21^{\prime} 30.2^{\prime \prime} \mathrm{N}$ and $124^{\circ} 49^{\prime} 2.8^{\prime \prime} \mathrm{E}$, (3) $1^{\circ} 24^{\prime} 23.70^{\prime \prime} \mathrm{N}$ and $124^{\circ}$ $52^{\prime} 17.30^{\prime \prime}$ E. Sampling in each location was conducted by making a soil profile, the depth of soil profile was made until it reached the soil parent materials. Soil samples were collected from each horizon layer, including the parent materials.

\section{Soil Analysis}

This study used the X-Ray Fluorescence (XRF) to analyze the percentage of elements and oxide minerals contained in the parent materials and Xray diffractometer (XRD) to identify the percentage of clay minerals from the soil. The XRD and XRF analyses were carried out in the laboratory of the Faculty of Natural Sciences, Hasanuddin University. Arc-GIS 10.3 Software was used for mapping the location of the study based on a regional geological map (scale 1: 250,000) and the topographic map (scale 1: 50,000) as the base maps. Analysis of soil samples including texture (hydrometer method), $\mathrm{pH}$ $\mathrm{H}_{2} \mathrm{O}$ (electrometric method), organic-C content (Walkley and Black method), and cation exchange capacity (CEC) (Ammonium Acetate method) were carried out in the Laboratory of Soil Chemistry and Soil Fertility, Department of Soil Science, Faculty of Agriculture, Hasanuddin University. 


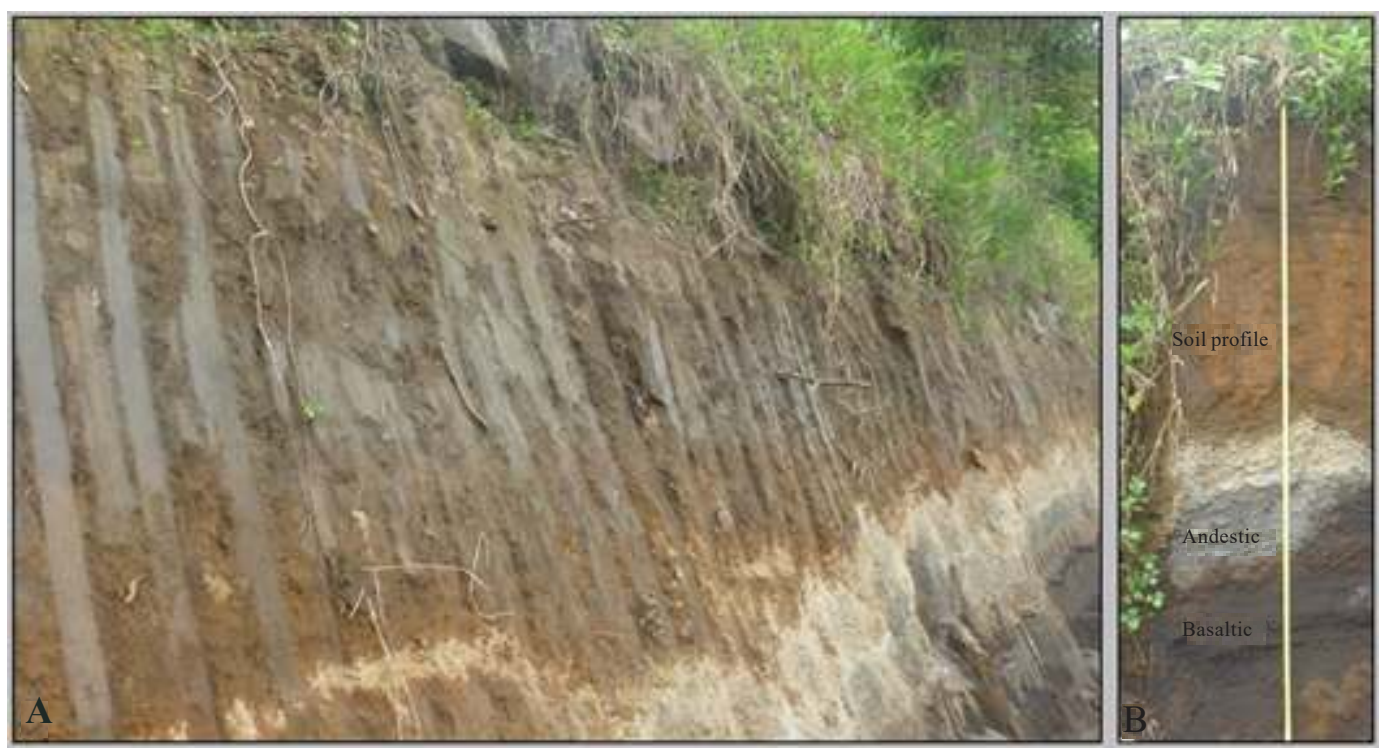

Figure 1. Soil profile development from two types of pyroclastic materials.

\section{RESULTS AND DISCUSSION}

There are two types of pyroclastic materials as a source of volcanic ash soil, namely 1) basaltic pyroclastic materials with $43.26 \% \mathrm{SiO}_{2}$ that are resulted from the first magmatic eruption and 2) andesitic pyroclastic materials with $5.09 \% \mathrm{SiO}_{2}$ that are resulted from late magmatic eruption (Figure 1). It shows that the time span of the volcanic eruption from Lokon Volcano is in a long phase in which the properties change from basaltic magma into andesitic (Table 1). Changing nature of the magma caused by the changes in gas and $\mathrm{H}_{2} \mathrm{O}$ content after the assimilation with groundwater and the wall rocks of the volcanic neck, then continuing with the fractionation process of magma with a higher $\mathrm{MgO}$ content into magma with high $\mathrm{K}_{2} \mathrm{O}$ content (Hawkesworth et al. 2000).

Basaltic pyroclastic materials contain $37.63 \%$ iron $(\mathrm{Fe})$, which is less than that in the andesitic pyroclastic materials that amount to $38.35 \%$, but the content of Aluminum (Al) in the basaltic pyroclastic is much larger than that in the andesitic pyroclastic, as well as the content of calcium (Ca) and magnesium (Mg) (Table 2). High aluminum content increases the formation of kaolinite minerals in the soil, which will have an impact on decreasing soil $\mathrm{pH}$ because it reduces the ability of the soil to bind cations, in which kaolinite only has the ability to bind cations by $1-10 \mathrm{cmol}(+) \mathrm{kg}^{-1}$ (Alani and Sarapaa, 2008), conversely the iron and magnesium content will influence the formation of vermiculite and montmorillonite minerals (Ugolini and Zasoski 1979; Van Der Weijden and Pacheco 2003). These minerals have the ability to bind cations by $40-120 \mathrm{cmol}(+) \mathrm{kg}^{-1}$, thereby increasing soil CEC (Table 3).

Rainfall in the study site ranges from $2000 \mathrm{~mm}$ $\mathrm{yr}^{-1}$ to $3500 \mathrm{~mm} \mathrm{yr}^{-1}$. This rainfall is classified as high and will increase the weathering process of

Table 1. Comparison of the chemical composition of oxides from basaltic and andesitic pyroclastic.

\begin{tabular}{lcclcc}
\hline & Basaltic & & & Andesitic & \\
\hline Composition & $\%(w / w)$ & Std. Err. & Composition & \% $(w / w)$ & Std. Err. \\
\hline $\mathrm{SiO}_{2}$ & 43.26 & 1.71 & $\mathrm{SiO}_{2}$ & 51.09 & 0.81 \\
$\mathrm{Fe}_{2} \mathrm{O}_{3}$ & 26.54 & 1.04 & $\mathrm{Fe}_{2} \mathrm{O}_{3}$ & 26.92 & 0.43 \\
$\mathrm{Al}_{2} \mathrm{O}_{3}$ & 14.09 & 1.33 & $\mathrm{CaO}$ & 10.24 & 0.17 \\
$\mathrm{CaO}$ & 6.69 & 0.26 & $\mathrm{Al}_{2} \mathrm{O}_{3}$ & 8.58 & 1.28 \\
$\mathrm{MgO}$ & 6.21 & 3.08 & $\mathrm{MnO}$ & 0.68 & 0.05 \\
$\mathrm{MnO}$ & 1.12 & 0.06 & $\mathrm{P}_{2} \mathrm{O}_{5}$ & 0.34 & 0.12 \\
$\mathrm{P}_{2} \mathrm{O}_{5}$ & 0.35 & 0.12 & $\mathrm{~K}_{2} \mathrm{O}$ & 0.31 & 0.12 \\
Others & 1.74 & 0.21 & Others & 1.83 & 0.20 \\
\hline
\end{tabular}


Table 2. Comparison of the chemical composition of elements from basaltic and andesitic pyroclastic.

\begin{tabular}{lcclcc}
\hline & \multicolumn{1}{l}{ Basaltic } & & & Andesitic & \\
\hline Composition & $\%(w / w)$ & Std. Err. & Composition & $\%(w / w)$ & Std. Err. \\
\hline $\mathrm{Fe}$ & 37.63 & 1.30 & $\mathrm{Fe}$ & 38.35 & 0.48 \\
$\mathrm{Si}$ & 32.42 & 1.16 & $\mathrm{Si}$ & 37.43 & 0.54 \\
$\mathrm{Al}$ & 11.35 & 1.08 & $\mathrm{Ca}$ & 13.17 & 0.17 \\
$\mathrm{Ca}$ & 8.61 & 0.30 & $\mathrm{Al}$ & 6.87 & 1.04 \\
$\mathrm{Mg}$ & 5.69 & 2.80 & $\mathrm{Mn}$ & 1.04 & 0.08 \\
$\mathrm{Mn}$ & 1.71 & 0.09 & $\mathrm{~K}$ & 0.45 & 0.17 \\
$\mathrm{Px}$ & 0.40 & 0.09 & $\mathrm{Px}$ & 0.37 & 0.09 \\
Others & 2.07 & 0.28 & Others & 2.32 & 0.24 \\
\hline
\end{tabular}

Table 3. Physical and chemical properties of soil developed from volcanic ash.

\begin{tabular}{|c|c|c|c|c|c|c|c|c|c|c|}
\hline \multirow{3}{*}{ Location } & \multirow{3}{*}{ Coordinates } & & & & \multirow{3}{*}{ Texture } & \multicolumn{3}{|c|}{ Org. } & Clay & \multirow{3}{*}{ Colors } \\
\hline & & Sand & Silt & Clay & & $\mathrm{pH}$ & $\mathrm{C}$ & $\mathrm{CEC}$ & $\mathrm{CEC}$ & \\
\hline & & \multicolumn{3}{|c|}{------- \% ------- } & & $\mathrm{H}_{2} \mathrm{O}$ & $\%$ & \multicolumn{2}{|c|}{$\left(\mathrm{cmol}(+) \mathrm{kg}^{-1}\right)$} & \\
\hline \multirow[t]{2}{*}{$\begin{array}{c}\text { I } \\
(30 \mathrm{~cm})\end{array}$} & $1^{\circ} 24^{\prime} 23.70^{\prime \prime} \mathrm{N}$ & 67 & 18 & 16 & Sandy loam & 6.2 & 1.72 & 23.24 & 148.93 & $\begin{array}{c}\text { 7.5YR 2.5/3 (Very } \\
\text { Dark Brown) }\end{array}$ \\
\hline & $124^{\circ} 52^{\prime} 17.30^{\prime \prime} \mathrm{E}$ & & & & & & & & & \\
\hline \multirow[t]{2}{*}{$\begin{array}{c}\text { II } \\
(0-60 \mathrm{~cm})\end{array}$} & $1^{\circ} 21^{\prime} 30.2^{\prime \prime} \mathrm{N}$ & 72 & 10 & 17 & Sandy loam & 6.3 & 2.03 & 20.65 & 120.74 & $\begin{array}{c}2.5 \text { Y } 3 / 1 \text { (Very } \\
\text { Dark Grey) }\end{array}$ \\
\hline & $124^{\circ} 49^{\prime} 2.8^{\prime \prime} \mathrm{E}$ & & & & & & & & & \\
\hline $\begin{array}{c}\text { IIIa } \\
(0-60 \mathrm{~cm}) \\
\text { IIIb }\end{array}$ & $1^{\circ} 21^{\prime} 18.0^{\prime \prime} \mathrm{N}$ & 73 & 10 & 17 & Sandy loam & 5.96 & 3.08 & 23.24 & 140.63 & $\begin{array}{l}\text { 10YR 2/1 (Black) } \\
7.5 \text { YR 3/4 (Dark }\end{array}$ \\
\hline$(60-130 \mathrm{~cm})$ & $124^{\circ} 49^{\prime} 20.2^{\prime \prime} \mathrm{E}$ & 80 & 2 & 18 & Sandy loam & 5.86 & 2.34 & 20.54 & 113.81 & Brown) \\
\hline
\end{tabular}

Table 4. The percentage of clay minerals contained in the volcanic ash soil.

\begin{tabular}{cccc}
\hline Formula & Type of Mineral & Name & Percentage (\%) \\
\hline $\mathrm{Al}_{2} \mathrm{H}_{4} \mathrm{O}_{9} \mathrm{Si}_{2}$ & $1: 1$ & Kaolinite & 37.2 \\
$\mathrm{C}_{12} \mathrm{Mg}_{3} \mathrm{~N}_{4} \mathrm{O}_{12} \mathrm{Si}_{4}$ & $2: 1$ & Vermiculite & 9.5 \\
$\mathrm{Al}_{1,2} \mathrm{Cr}_{0,7} \mathrm{Fe}_{0,1} \mathrm{H}_{7,9} \mathrm{Mg}_{5} \mathrm{O}_{18} \mathrm{Si}_{3}$ & $2: 2$ & chlorite & 14.1 \\
$\mathrm{Al}_{0,86} \mathrm{Fe}_{0,1} \mathrm{HLi}_{0,08} \mathrm{Mg}_{0.14} \mathrm{O}_{10} \mathrm{Si}_{3,9}$ & $2: 1$ & Montmorillonite & 5.9 \\
$\mathrm{Al}_{2} \mathrm{H}_{8} \mathrm{O}_{11} \mathrm{Si}_{2}$ & $1: 1$ & Halloysite & 33.4 \\
\hline
\end{tabular}

Note: The data were derived from XRD analysis.

parent rocks from Qv (Quarter Volcanics) Formations (Effendi and Bawono 1996), with the composition of Qv Formation includes andesiticbasaltic lava, bombs, lapilli and volcanic ash (Figure 2). Characteristics of soil parent material derived from andesitic lava have a fairly high resistance to weathering activity so that the soil texture that is formed is mainly sandy loam. The soil contains $3.08 \%$ organic-C derived from dryland forests that dominate the land use of the study site. The content of soil organic matter enhances the soil ability to bind cations and increase the soil CEC (Table 3). Collaboration with clay minerals reached a CEC of $23.24 \mathrm{cmol}(+) \mathrm{kg}^{-1}$ and clay CEC of $148.93 \mathrm{cmol}(+)$ $\mathrm{kg}^{-1}$.
The soil organic matter content is classified in a moderate level (BPT 2005). In the toe slope of Mount Lokon, the organic matter content decreases caused by the high decomposition rate of organic matter due to increasing the soil temperature. The soil temperature increases due to the increase of volcanic activity at the study site, where the soil surface in the volcanic eruption area is generally covered by lava, pyroclastic flows, and tephra (volcanic ash) (Rahayu et al. 2014). The soil CEC is considered in a moderate level (BPT 2005). The soil CEC is strongly influenced by soil colloids (organic matter and clay minerals). The presence of clay minerals type $2: 1$, although only $15.4 \%$ of the total clay mineral content (Table 4), has 


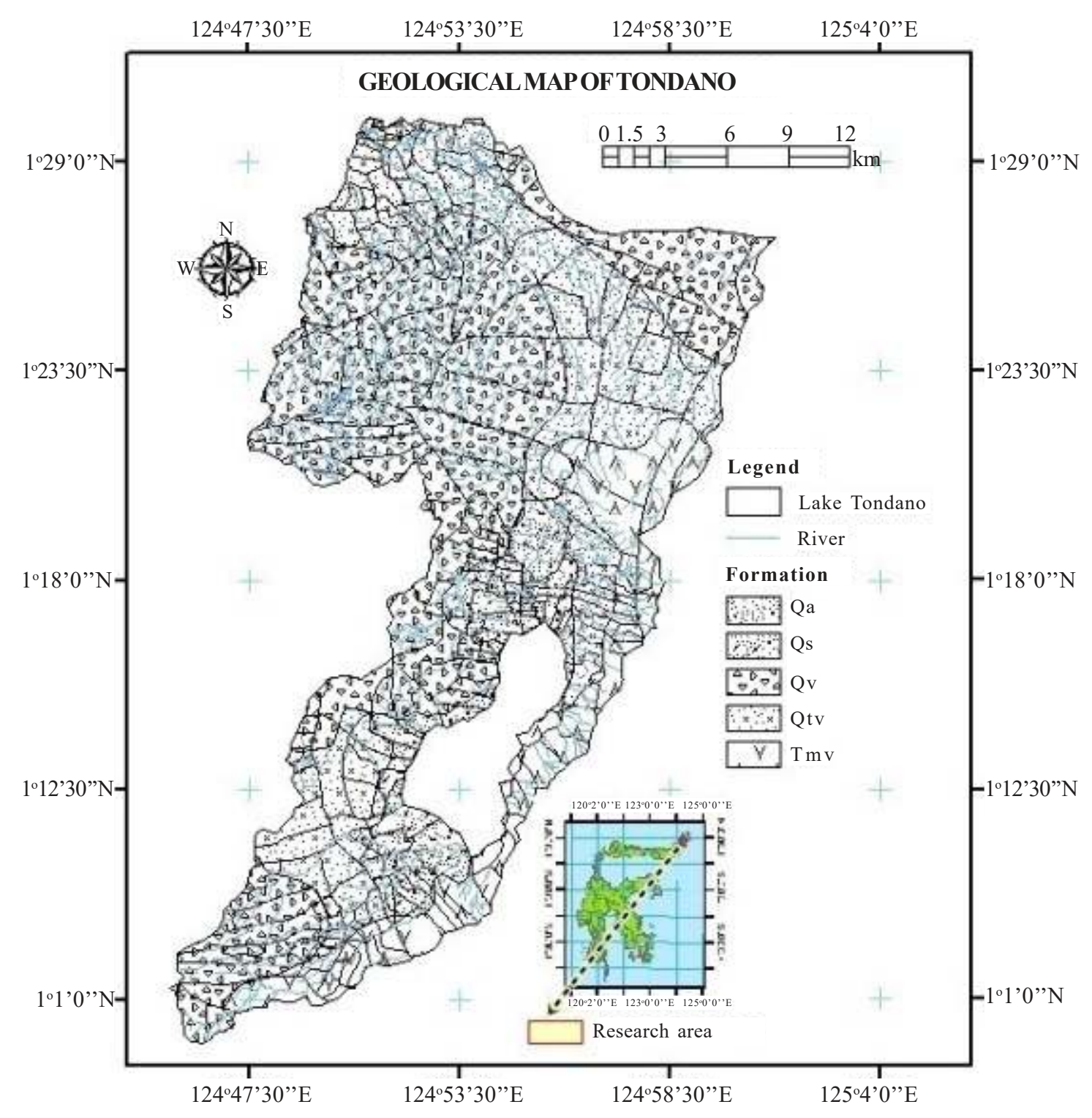

Figure 2. Geological map of Tondano Watershed and the study location in the foot slope of Mt. Lokon with the parent rocks from Qv Formation.

contributed to improving the exchange of cations due to the interlayer space of the clay mineral type $2: 1$ is larger than the clay mineral type 1:1 (Borisover and Davis 2015).

The predominant clay minerals found in the soil is kaolinite and halloysite (Table 4), due to the high weathering rate of parent materials with high content of aluminum and silica (Table 2). Andesitic pyroclastic influences the formation of kaolinite and halloysite minerals. The results of current study is in line with the results of a study by Yatno and Zauyah (2008) that found an abundance of halloysite minerals in soils developed from andesitic pyroclastic materials in the area of Lembang, West Java. On the other hand, the results of study by Ahmad et al. (2018) found the formation of kaolinite minerals by $33.6 \%$ in soils originating from andesitic parent material from areas with high rainfall (2780 $\mathrm{mm} \mathrm{yr}^{-1}$ ) in Gowa Regency, South Sulawesi. This result indicates that the intensity of the formation of kaolinite and halloysite minerals can occur in areas developed from parent materials derived from volcanic activity with andesitic type in high rainfall area.

\section{CONCLUSIONS}

There are two types of pyroclastic materials as sources of volcanic ash soil, namely basaltic pyroclastic with $43.26 \% \mathrm{SiO}_{2}$ resulted from the first magmatic eruption and andesitic pyroclastic with $51.09 \% \mathrm{SiO}_{2}$ mainly from the late magmatic eruption. 
The soil has a predominantly sandy loam texture, with organic-C content $3.08 \%$, CEC $23.24 \mathrm{cmol}(+)$ $\mathrm{kg}^{-1}$, clay CEC $148.93 \mathrm{cmol}(+) \mathrm{kg}^{-1}$ and $\mathrm{pH}$ 5.9-6. The predominant clay minerals found in the volcanic ash soil are kaolinite and halloysite.

\section{ACKNOWLEDGMENTS}

We thank the Directorate General of Higher Education (DIKTI) and LP2M of Hasanuddin University for the grants through university grants.

\section{REFERENCES}

Ahmad A, C Lopulisa, AM Imran and S Baja. 2018. Soil classification at family categories from tertiary volcanic rock formation with different type of lithology: a case study of Indonesia. Inter J Eng Sci Res Tech 7: 349-359.

Arnalds O. 2013. The influence of volcanic tephra (ash) on ecosystems', in Advances in Agronomy. 1st edn. Copyright (C 2013 Elsevier Inc., pp. 331-380. doi: 10.1016/B978-0-12-407685-3.00006-2.

Babiera VV and T Takahashi. 1997. Characteristics of soils derived from tephra and pyroclastic flow deposits from taal volcano, the philippines', Soil Sci Plant Nutr 43: 763-776. doi: 10.1080/ 00380768.1997.10414643.

Borisover M and JA Davis. 2015. Adsorption of Inorganic and Organic Solutes by Clay Minerals', in Develop Clay Sci: 33-70. doi: 10.1016/B978-0-08-1000274.00002-4.

BPT. 2005. Analisis kimia tanah, tanaman, air dan pupuk, Badan penelitian dan Pengembangan. Available at: http://balittanah.litbang.pertanian.go.id/ind/ dokumentasi/juknis/juknis_kimia. pdf. (in Indonesian).

Cronin SJ, C Stewart, AV Zernack, M Brenna, JN Procter, N Pardo, B Chritenson, T Wilson, RB Stewart and M Irwin. 2014. Volcanic ash leachate compositions and assessment of health and agricultural hazards from 2012 hydrothermal eruptions, Tongariro, New Zealand', J Volcanol Geoth Res 286: 233-247. doi: 10.1016/j.jvolgeores.2014.07.002.

Dahlgren RA, M Saigusa and FC Ugolini. 2004. The Nature, Properties and Management of Volcanic Soils', in Advances in Agronomy. Academic Press, pp. 113-182. doi: 10.1016/S0065-2113(03)82003-5.

Dariah A, SL Sutono, N Nurida, W Hartatik and E Pratiwi. 2015. Pembenah Tanah untuk Meningkatkan Produktivitas Lahan Pertanian', J Sumberdaya Lahan 9: 67-84.
Effendi AC and SS Bawono. 1996. Peta Geologi Regional Manado 1:250.000' Pusat Penelitian dan Pengembangan Geologi. Bandung, Indonesia. (in Indonesian).

Gourgaud A, JC Thouret and JL Bourdier. 2000. Stratigraphy and textural characteristics of the 198283 tephra of Galunggung volcano (Indonesia): Implications for volcanic hazards', $J$ Volcanol Geoth Res 104: 169-186. doi: 10.1016/S03770273(00)00205-5.

Hall R. 2012. Late Jurassic-Cenozoic reconstructions of the Indonesian region and the Indian Ocean', Tectonophysics. Robert Hall, 570-571, pp. 1-41. doi: 10.1016/j.tecto.2012.04.021.

Hawkesworth CJ, S Blake, P Evans, R Hughes, R Macdonald, LE Thomas, SP Turner and G Zellmer.2000. Time scales of crystal fractionation in magma chambers-integrating physical, isotopic and geochemical perspectives', J Petrol 41: 991-1006. doi: 10.1093/petrology/41.7.991.

Katili JA. 1975. Volcanism and plate tectonics in the Indonesia Island arcs', Tectonophysics 26:165-188. doi: 10.1016/0040-1951(75)90088-8.

Prévosto B, E Dambrine, C Moares and T Curt. 2004. Effects of volcanic ash chemistry and former agricultural use on the soils and vegetation of naturally regenerated woodlands in the Massif Central, France', Catena 56: 239-261. doi: 10.1016/ j.catena.2003.10.014.

Rahayu, DP Ariyanto, Komariah, S Hartati, J Syamsiyah and WS Dewi. 2014. Dampak Erupsi Gunung Merapi Terhadap Lahan Dan Upaya-Upaya Pemulihannya', Caraka Tani - J Ilmu Ilmu Pertanian 29: 61-72. doi: 10.20961/carakatani.v29i1.13320.

Siebert L, E Cottrell, E Venzke and B Andrews. 2015. Earth's volcanoes and their eruptions: An overview', In: $\mathrm{H}$ Sigurdsson, B Houghton, SR McNutt, H Rymer and J Stix (eds). Encyclopedia of Volcanoes Second Edition. 2nd edn. San Diego, pp. 239-255. doi: 10.1016/B978-0-12-3859389.00012-2.

Torrence R. 2012. Volcanic disasters and agricultural intensification: A case study from the Willaumez Peninsula, Papua New Guinea', Quatern Int 249: 151-161. doi: 10.1016/j.quaint.2011.03.041.

Ugolini F and R Zasoski. 1979. Soils Derived from Tephra', in Volcanic Activity and Human Ecology. Academic Press Inc, pp. 83-91.

Van Der Weijden and FAL Pacheco. 2003. Hydrochemistry, weathering and weathering rates on Madeira island', J Hydrology 283: 122-145. doi: 10.1016/S0022-1694(03)00245-2.

Yatno E and S Zauyah. (2008). Properties and management implication of soils formed from volcanics materials in Lembang Area West Java. Ind J Agri Sci 9: 44-54. 